\title{
ARISTÓTELES: A JUSTIÇA SE DIZ DE MUITOS MODOS
}

\section{Liliam Ferraresi Brighente $^{1}$}

\begin{abstract}
Por isso frequentemente, ainda hoje - e não por acaso é assim há dois mil anos -, a leitura de uma página de Aristóteles faz pensar, faz refletir, faz meditar, ensina algo acerca do sentido de certas realidades, algo diferente do que se pode aprender pelas obras de ciência ou de literatura, ou ainda de poesia. (BERTI, 1997, p. 326)
\end{abstract}

\section{Resumo}

O presente artigo analisa a concepção de justiça em Aristóteles e o lugar que nela ocupa o direito. A justiça, para o filósofo grego, não é um termo unívoco, mas apresenta-se em sentidos diversos. Inicialmente, procura-se explicitar estes sentidos com apoio em bibliografia contemporânea e a partir de questões colocadas pela filosofia do direito. Em seguida, utilizando o método hermenêutico, através da análise e comentário de passagens do texto da Política, busca-se examinar um exemplo prático de aplicação desta concepção de justiça por meio da análise crítica que o filósofo faz do regime político da democracia. Por fim, após ter apresentado uma possível leitura da referida concepção, a qual revela a originalidade de Aristóteles na complexa articulação de todos esses sentidos de justiça, e já a título de conclusão, se procura ilustrar a atualidade da filosofia do direito aristotélica indicando a sua presença em dilemas contemporâneos, a exemplo do conhecido debate entre comunitaristas e liberais sobre o modo de se pensar a cidadania e a democracia.

Palavras-chave: Aristóteles; Filosofia do Direito; Justiça; Direito Natural; Democracia

\section{INTRODUÇÃO: OS FUNDAMENTOS DO DIREITO COMO OS VÁRIOS SENTIDOS DE JUSTIÇA}

O tema escolhido para análise e interpretação neste artigo situa-se, de um ponto de vista mais amplo, nos escritos éticos e políticos de Aristóteles. Estes escritos compõem o que a tradição convencionou chamar a filosofia prática, a qual abriga obras clássicas como a Política, a Ética a Nicômaco, os Econômicos, a Ética a Eudemo, a Magna Moralia, e a Constituição de Atenas, descoberta apenas no século XIX, e que inaugura a história das constituições.

\footnotetext{
${ }^{1}$ Doutoranda em Direito da Universidade Federal do Paraná. Colaboradora na Revista da Faculdade de Direito da Universidade Federal do Paraná. E-mail: brighente@yahoo.com
} 
Portanto, no campo dos estudos aristotélicos de filosofia prática, escolheu-se dedicar estas páginas, especificamente, à filosofia do direito. O que se busca é situar o lugar do direito no panorama mais amplo da justiça, tal qual compreendida pelo filósofo grego, razão pela qual o texto se concentrará primeiramente, sobretudo, no capítulo V da Ética a Nicômaco, com algumas remissões à Política à Retórica.

A pergunta fundamental que se busca responder é: o que é para Aristóteles o direito? Uma boa maneira de procurar a resposta é começar mostrando de onde Aristóteles partiu para construir sua definição. Ou seja, mostrar como ele dialogava com seus contemporâneos, sobretudo, com seu mestre Platão.

Em seguida, pretende-se desenvolver mais detalhadamente a concepção própria de Aristóteles acerca dos vários sentidos de justiça, do significado de direito natural e positivo, de equidade e da relação do direito com a ética.

Por fim, estuda-se essa concepção por meio da análise de um exemplo retirado da própria filosofia política de Aristóteles: a democracia. O último tópico parte desta mesma noção para ilustrar o vigor da contribuição de Aristóteles ainda atuante na discussão entre comunitaristas e liberais kantianos acerca das concepções de cidadania e democracia.

\section{A TEORIA DA JUSTIÇA DE ARISTÓTELES: A JUSTIÇA NATURAL E A JUSTIÇA POLÍTICA}

Aristóteles entende a justiça como uma virtude. Por virtude, chama o meio-termo que se encontra entra a falta e o excesso, por exemplo, "a coragem éo justo termo entre a temeridade e a covardia" (1220b38-1221a12). A justiça, no entanto, é uma virtude de natureza diversa das demais. Enquanto as outras virtudes podem chamar-se virtudes individuais, cuja excelência pode ser alcançada apenas com o esforço do próprio virtuoso, a justiça é uma virtude voltada para o outro. Ou no dizer de Richard Bodéüs, repetindo as palavras de Aristóteles: a justiça é uma virtude "que implica necessariamente todas as outraš. (Bodéüs, 2007, p. 67)

Ademais, o problema da justiça é mais complexo, pois ela não se diz somente em um sentido. JeanCassien Billier e Aglaé Maryioli escrevendo sobre a História da Filosofia do Direito, explicam o conceito de direito aristotélico² $^{2}$ Para eles, a mudança de paradigma filosófico operada por Aristóteles em relação a seu mestre Platão, se mostra no direito, pela transformação que Aristóteles realiza "quanto à idéia de natureza." (Billier e Maryioli, 2005, p. 79).

\footnotetext{
${ }^{2} \mathrm{O}$ leitor também pode consultar outros estudos contemporâneos, como o de Solange Vergnières, intitulado Ética e Política em Aristóteles: physis, ethos, nomos (2008, editora Paulus), que problematiza o tema a partir dos termos gregos, bem como estudos mais clássicos como o de W. D. Ross, Aristotle (Londres, 1923), o de Jonathan Barnes, Aristóteles (Loyola, 2005), o de F. Wollf, Aristotle et la politique (Paris, 1991, Puf), o de Enrico Berti, As razões de Aristóteles (2002, edições Loyola), etc., que apresentam abordagens próprias e por isso conduzem a interpretações que pode divergir da aqui proposta.
} 
Platão, para responder a oposição sofista da natureza e da lei:

[...] a essa dupla aporética physis-nomos, propusera uma "sobrenatureza": o verdadeiro estava na ordem inteligível de cujos entes aparentes e sensíveis eram mera imitação. Aristóteles rejeita essa ontologia das Essências, reelaborando a sua maneira a noção de physis. A "forma" na filosofia de Aristóteles não é separada da realidade, não é transcendente a ela, mas é um princípio de organização imanente. A natureza é matéria e forma, persegue um fim (telos) sem estar certa de atingi-lo, e tem o valor de uma norma. (BILLIER, 2005, p. 81).

Nesse sentido, à pluralidade sensível Aristóteles confere uma unidade, embora não mais transcendente como era em Platão, e sim imanente. Na Retórica, por exemplo, lê-se:

Chamo lei tanto à que é particular como a que é comum. É lei particular tanto a que é definida por cada povo em relação a si mesmo, quer seja escrita ou não escrita; e comum a que é segundo a natureza. Pois há na natureza um princípio comum do que é justo e injusto, que todos de algum modo adivinham mesmo que não haja entre si comunicação ou acordo. (Ret. 1373b)

Ou seja, as leis positivas sejam ou não escritas (o que inclui os costumes) devem remeter a uma lei mais fundamental, comum e eterna, a um justo natural. No entanto, essa oposição é simplista e Aristóteles logo se apercebe disto: ela meramente opõe um direito natural como figura abstrata e universal em face de um direito positivo que seria mera convenção dos homens. O resultado é o enfraquecimento de ambos. Aliás, essa é a tese sofista que tanto Aristóteles como Platão buscam combater.

A originalidade de Aristóteles se mostra na maneira como ele resolverá este problema, articulando estreitamente o direito natural e o direito positivo ao invés de apartá-los.

A partir do Capítulo X do Livro V da Ética a Nicômaco, Aristóteles trata da justiça, operando primeiro uma divisão entre justo no sentido absoluto e justo no sentido político. O primeiro tem um sentido moral e é propriamente o justo natural.

O justo natural também é chamado de justiça geral, embora Aristóteles não use esse termo. A justiça geral é uma atividade a serviço da ordem cósmica universal. Se cada coisa possui uma finalidade dada pela natureza, a justiça está em conservá-las no seu lugar estabelecido na ordem do universo e a injustiça em desequilibrar esta ordem natural, deslocando-as.

O justo no sentido político, no entanto, é em parte natural e em parte legal (positivo). Para esclarecer esta articulação positivo-natural "Aristóteles nos convida a pensar o natural como o que tem em todo lugar o mesmo poder, e o positivo, o legal', como o que é colocado por convenção aqui e ali, e vem, pois, a particularizar a justiça natural." (Billier, 2005, p. 82).

Na Ética a Nicômaco Aristóteles afirma:

Da justiça política, uma parte é natural e outra parte legal: natural, aquela que tem a mesma força onde quer que seja e não existe em razão de pensarem os homens deste ou daquele modo; legal, a que de início é indiferente, mas deixa de sê-lo depois que foi estabelecida... [....] Ora alguns pensam que toda justiça é desta espécie, porque as coisas que são por natureza são imutáveis e em toda parte têm a mesma força (como o fogo, que arde tanto aqui como 
na Pérsia), ao passo que eles observam alterações nas coisas reconhecidas como justas. Isso, porém, não é verdadeiro de modo absoluto, enquanto para nós existe algo que é justo mesmo por natureza, embora seja mutável. Isso não obstante, algumas coisas o são por natureza e outras não.

Com todo evidência apercebe-se que espécie de coisas, entre as que são capazes de ser de outro modo, é por natureza e que espécie não o é, mas por lei e convenção, admitindo-se que ambas sejam igualmente mutáveis. E em todas as outras coisas a mesma distinção será aplicável: por natureza, a mão direita é mais forte; e no entanto é possível que todos os homens venham a tornar-se ambidestros.

As coisas que são justas em virtude da convenção e da conveniência assemelham-se a medidas, pois que as medidas para o vinho e para o trigo não são iguais em toda parte. E as próprias constituições não são as mesmas, conquanto só haja uma que é, por natureza, a melhor em toda parte. ${ }^{3}$

O importante é observar que essa definição não institui entre o natural e o legal uma oposição radical, mas ao contrário, o legal é a realização do justo natural.

O raciocínio Aristotélico remete a uma interpretação nova da idéia de natureza: se a natureza física é a mesma em todos os lugares ('o fogo queima tão bem aqui quanto entre os Persas'), a natureza humana é variável e sujeita a uma indeterminação essencial. A esse respeito, a 'conformidade com a natureza' não se pode pensar em termos de universalidade, mas antes de variabilidade. Em suma o direito natural não deve ser compreendido como uma universalidade separada, sobre o modo platônico de uma supernatureza, mas antes como aquilo que acompanha a variabilidade humana. (BILLIER, 2005, p. 82-83).

Ou seja, a variabilidade das leis não é para Aristóteles sinônimo de artificialidade, ao contrário, a tentativa de impor leis universais é que é contra a natureza. Todavia, a explicação ainda está incompleta, pois Aristóteles afirma que tanto o direito natural quanto o direito positivo são variáveis, mas de modos diferentes.

O direito natural varia tanto em sua forma quanto em seu conteúdo, enquanto que o positivo mantém a forma variando apenas o conteúdo. De fato, o conteúdo é totalmente contingente não derivando de nenhum princípio anterior.

Isso significa dizer que não há nada em comum entre os direitos positivos a não ser a sua possibilidade de tradução. Isto é, não há entre eles uma comunidade abstrata (como em Platão), mas há uma comunicabilidade². Essa conversibilidade entre os direitos positivos seria o direito natural ${ }^{5}$. Mais precisamente, o direito natural é o lugar dessa conversão. Trata-se de um horizonte sobre o qual os direitos positivos devem ser pensados. Uma espécie de “idéia reguladora” que permite dar sentido aos direitos positivos ${ }^{6}$.

Eis a complexidade do conceito de natureza Aristotélico expresso na definição de justiça:

Aristóteles, com efeito, associa face a face as duas atitudes tradicionais (em seu tempo como

\footnotetext{
${ }^{3}$ EN 1134b20-30 a $1135 a 5$.

${ }^{4} \mathrm{O}$ crédito desta interpretação deve ser dado a Pierre Aubenque, citado pelos autores, e pode ser encontrada no artigo La loi selon Aristote, Archives de Philosophie du Droit, 1980, vol. 25., p. 147.

5 "Essa concepção aristotélica do direito natural é pelo menos engenhosa. Ela supõe uma superação da concepção tradicional que opõe um direito universal, comum a todos os homens e na maioria das vezes associado pelos gregos à esfera do não escrito, e um direito particular." (Billier, 2005, p. 83)

6 "Sem dúvida é preciso insistir nessa dupla refutação que é realizada por Aristóteles, e que torna sua posição tão complexa ou, para certas pessoas, obscura." (Billier, 2005, p. 85.)
} 
no nosso!): a de puro convencionalismo ou puro positivismo jurídico, que nega toda justiça natural, todo direito não instituído; e a do naturalismo, que toma uma 'origem' incompreensível do instituído no não instituído, ou ainda uma crítica das leis positivas em nome de um princípio separado. Com Aristóteles, é afligida de inanição tanto a redução do justo ao legal como a tentativa de introduzir uma legalidade natural. Permanece, pois, essa estranheza filosófica: um justo natural mas mutável, e não imutável[...]. (BILLIER, 2005, p. 84)

Nesse sentido, já é possível perceber que a natureza aristotélica não equivale a um conceito geral e abstrato universalmente aplicável a toda a humanidade. Não há uma oposição entre um direito universal comum a todos os homens e um direito particular. Aliás, não existe sequer essa universalidade "a humanidade". Eis porque os "direitos humanos" são impensáveis na filosofia aristotélica.

Isso significa também que Aristóteles não parte da igualdade entre todos os seres humanos, ao contrário, sua natureza humana distingue, diferencia entre os vários estados morais, entre as várias relações hierárquicas de comandantes e comandados, de virtuosos e de inaptos politicamente. Como diz Brugnera: "as diferentes formas de participação dos indivíduos na comunidade política resultam ser, concomitantemente, diferentes formas de ser homem" (Brugnera, 1998, p. 91) e também significam estados jurídicos diversos. Mais adiante, este ponto ficará mais claro quando se examinar a visão que possui o filósofo sobre o regime político da democracia.

\section{A JUSTIÇA PARTICULAR: O DIREITO POSITIVO E A EQUIDADE}

O direito positivo, para alguns intérpretes de Aristóteles, manifesta-se propriamente como justiça particular. Ou seja, há duas formas dessa relação se estabelecer: distributiva ou corretivamente.

Essas duas espécies de relações proporcionais são participações do direito natural no direito positivo (duas formas naturais do direito positivo). Portanto, já são direito positivo, visto que dizem respeito à justiça que se estabelece entre as partes, a cada uma considerada singularmente.

Por justiça distributiva se pode entender a atribuição a pessoas de divisões de bens. Essa distribuição será considerada justa apenas se pessoas iguais receberem parcelas iguais. Aristóteles nota que é mais fácil estabelecer a divisão igualitária das coisas do que a igualdade das pessoas: "pois todos admitem que a distribuição justa deve concordar com o mérito num sentido qualquer, se bem que nem todos especifiquem a mesma espécie de mérito [...]" (EN 1131a25). E acrescenta que os democratas estabelecem essa igualdade na condição de homem livre, os oligarcas na riqueza ou na nobreza de nascimento e os aristocratas na excelência. Isto é, a relação proporcional toma a forma (natural) da justiça distributiva, porém o critério segundo o qual a divisão será feita é variável porque estabelecido pelas leis de cada comunidade política.

Sob este prisma, o justo nas divisões de bens a pessoas é sempre uma espécie de termo proporcional(EN 1131a30), que na justiça distributiva se manifesta numa igualdade "geométrica". Young dá um exemplo desta espécie de proporção: 
Uma distribuição envolvendo duas partes, por exemplo, Sócrates e Platão, será justa se, e somente se, o valor da parcela distribuída a Sócrates corresponder ao valor de Platão, e o valor for medido por um padrão correto qualquer.” Assim, se ambos tiverem investido dinheiro em um empreendimento, na hora de distribuir os ganhos, se deve considerar como medida da igualdade o tamanho do investimento que cada um fez. "Suponhamos que Sócrates tenha investido 20 dracmas, que Platão tenha investido 10 dracmas, e que eles tenham 60 dracmas de ganhos para dividir entre si. Obviamente é justo dar a Sócrates, que investiu duas vezes mais do que Platão, o dobro dos ganhos dados a Platão, perfazendo-se assim 40 dracmas para Sócrates e 20 para Platão. Uma distribuição injusta seria aquele que violasse essa proporção. (2009, p. 174-175.)

De outro lado, a justiça corretiva estabelece a relação de proporção de acordo com uma igualdade dita “aritmética”. Ela não trata de uma divisão, mas de uma reparação entre pessoas que se encontravam em uma situação de igualdade que foi desfeita. Nestes casos, não importa o mérito da pessoa envolvida:

[...] porquanto não faz diferença que um homem bom tenha defraudado um homem mau ou vice-versa, [...] a lei considera apenas o caráter distintivo do delito e trata as partes como iguais, se uma comete e a outra sofre injustiça, se uma é autora e a outra é vítima do delito. (EN 1132a5).

Novamente, o exemplo de Young é esclarecedor:

[...] se Platão tem 10 dracmas que pertencem a Sócrates, a justiça corretiva retirará as 10 dracmas de Platão, restituindo-as a Sócrates. Sócrates verá a sua posição melhorada após a correção na mesma quantidade em que Platão verá a sua piorada, ou seja, em 10 dracmas. (2009, p. 175).

Villey, lendo as páginas de Aristóteles, observou que "no Livro V da Ética, há uma definição do direito, a primeira pelo que eu saiba, e certamente não a menor, de todas as filosofias do direito." (2007, p. 44).

Para ele, é na justiça particular que se encontra propriamente o direito grego, o qual tem por finalidade "que ninguém tome mais ou receba menos que sua parte dos bens exteriores partilhados num grupo" (Villey, 2007, p. 42).

De acordo com Villey, extrai-se do Livro $\mathrm{V}$ uma estrutura geral aplicável tanto à justiça distributiva quanto à justiça corretiva. Isto é, o direito enquanto justiça particular possuiria três atributos: um objeto, uma proporção e um método.

O objeto visa à justa partilha dos bens e dos ônus que consiste numa relação: "o conceito de direito pressupõe uma pluralidade de pessoas entre as quais ocorreu uma partilha de bens exteriores." (Villey, 2007, p.45). Em segundo lugar, há uma proporção (medida adequada) que é efeito da partilha proporcional dos bens repartidos: "o direito de cada qual que ela define, é o produto dessa divisão, uma quantidade sempre finita. E as partes de uns e outros não serão iguais ${ }^{7} . "(2007$, p. 47, grifo do autor).

E por último, existe um método que é o dialético. Parte-se dos extremos e procura-se o meio, mediante a observação da realidade social que considera a confrontação de diversos pontos de vistas sobre essas realidades

\footnotetext{
${ }^{7}$ Atente-se para isso, "os direitos reconhecidos as diversas pessoas serão desiguais" (Villey, 2007, p. 49). A justiça quanto mais se aproxima de seu termo, isto é, a medida adequada ou equidade perfeita, mais chances terá de resultar em desigualdades de direitos.
} 
(as opiniões mais comuns). Isso porque cada opinião reflete um aspecto da realidade. ${ }^{8}$

Villey ressalta que não se concebe essa partilha de bens sem a presença de um juiz (partilha que na verdade já foi realizada, mas cuja justiça cabe ao juiz verificar) dotado de poder para resolver a questão por meio de uma sentença.

A sentença tem o estatuto de uma opinião que não é cientificamente comprovada e, não obstante, é fundamentada porque resultante da controvérsia dialética que levou em conta as várias opiniões em discussão. Com este proceder, a dialética vai forjando regras gerais de direito. A título de conclusão, acrescenta:

[...] segundo a análise de Aristóteles, descobre-se o direito mediante observação da realidade social e confrontação dos pontos de vista diversos sobre essa realidade, porque o direito, objeto da justiça no sentido particular da palavra, é precisamente esse meio, a proporção certa das coisas partilhadas entre membros de um grupo político. (VILLEY, 2007, p. 52).

Sob este prisma, afirmam Billier e Maryioli, o direito aristotélico não reside na lei, mas na equidade. Devese entender essa afirmação no mesmo sentido em que Villey vinha sublinhando: o direito visa sempre a um ato de estabelecimento ou de restabelecimento da equidade, vale dizer, da repartição igual, porém não igualitária.

Desta forma, a aplicação de regras segundo o critério da equidade é o lugar do direito. A equidade tem o sentido de "ajustamento da legalidade" (2009, p. 86), pois "aplicar regras por definição formais e abstratas a casos por definição particulares e concretos éo direito." (2009, p. 88, grifo dos autores)

Assim sendo, dada a definição de direito traçada até aqui, é lícito perguntar se em Aristóteles o direito se separa da ética.

\section{DIREITO E ÉTICA}

Billier e Maryioli (2009, p. 89) propõe dizer que o direito se distingue da ética, contudo não se separa dela totalmente. Isto porque, em verdade, Aristóteles subordina o direito e a ética ao político. Logo na abertura da Ética a Nicômaco, Aristóteles escreve a respeito do sumo bem?:

Ninguém duvidará que o seu estudo pertença à arte mais prestigiosa e que mais verdadeiramente se pode chamar a arte mestra. Ora, a política mostra ser dessa natureza, pois é ela que determina quais as ciências que devem ser estudadas num Estado, quais são as que cada cidadão deve aprender, e até que ponto; e vemos que até as faculdades tidas em maior apreço, como a estratégia, a economia e a retórica, estão sujeitas a elas. Ora, como a política utiliza as demais ciências e, por outro lado, legisla sobre o que devemos e o que não devemos fazer, a finalidade dessa ciência deve abranger as das outras [...]" (EN 1094a305 a 1094b7)

Ou seja, a política determina o fim de todas as demais artes, inclusive da arte jurídica. Viver conforme as leis é na Grécia antiga a lei suprema: esse também era o dito de Sócrates que preferiu submeter-se à morte tomando a cicuta do que desobedecer a sentença que lhe condenava, pois isso significaria desonrar as leis da

\footnotetext{
8 "Impõem-se em todo processo primeiro ouvir o pleito dos dois adversários e então confrontar as teses opostas dos jurisconsultos, uma das quais quer que seja atribuído demais e a outra não o bastante. (Villey, 2007, p. 51).

${ }^{9} \mathrm{O}$ sumo bem para os homens é a eudaimonia ou a felicidade.
} 
cidade.

Em outros termos, o direito aristotélico é eminentemente político: como arte da divisão equitativa ele pressupõe uma instituição que exerça essa divisão (os juízes) e uma comunidade política na qual isso tenha lugar. A mesma observação se pode ler em Villey: "Não há direito sem juízes, não existem juízes, e juristas para aconselhá-los, senão em cidades organizadas." (2007, p. 43)

Eis porque não existe direito na família, mas apenas relações de economia e o "direito" que se estabelece entre seus integrantes é apenas similar ao direito, um "quase-direito".

Por outro lado, também não é correto dizer que Aristóteles faça do jurista um moralista. Não cabe ao jurista tornar um homem justo, no sentido de desenvolver suas disposições interiores para a prática de atos justos. Esta é a tarefa da educação e do hábito.

Ao legislador, entretanto, incumbe fazer boas leis subordinando sempre o bem individual ao bem coletivo. Uma comunidade política na qual os cidadãos não cultivam a virtude não pode conduzir à felicidade e, portanto, não pode alcançar a excelência da vida humana.

Sob este prisma:

A regulação social realizada pelo Estado por meio das leis tem então um estatuto difícil de apreender: sem ser uma 'moralização', ela permanece ligada à ética na subordinação de todas as esferas ao político, visto que o Estado não é uma simples aliança contingente, mas uma união orgânica necessária que tem por fim a virtude e a felicidade de todos. (BILLIER, 2005, p. 88).

Por conseguinte, é mais acertado dizer que em Aristóteles há uma intersecção entre a esfera ética e a jurídica, entre o aspecto privado e público da justiça particular porque de seu caráter público participa o direito natural, mais próximo a uma ordem moral.

Sustentar o contrário seria aproximar Aristóteles de um filósofo moderno, o qual supõe uma rígida separação entre ética e direito. Aristóteles é um filósofo antigo e como dizem Billier e Maryioli, "é para sua doutrina do direito natural que devemos retornar afinal, para tentar a apreender a especificidade de sua filosofia do direito"(2007, p. 89).

Em síntese, quanto à filosofia do direito, a originalidade de Aristóteles, agora se entende mais claramente, consiste no fato de que ele não aloca em polos opostos o direito natural e o direito positivo porque ambos são duas faces do justo político. Por outras palavras, o justo natural (justo no sentido absoluto) é imanente e não transcendente ao justo político:

[...] não pensar um direito natural abstrato e separado: mesmo conservando uma distinção clara entre direito natural e direito positivo, Aristóteles consegue evitar produzir uma definição formal do direito natural, a mesma que conduzirá às grandezas e aos impasses do jusnaturalismo moderno. (BILLIER, 2007, p. 90).

Isso importa em sustentar que todo direito positivo é uma particularização da justiça natural e que todo direito natural é mutável, uma vez que se traduz na conversibilidade dos direitos positivos. 
Já o direito positivo (ou legal) se manifesta mais propriamente como justiça particular, de duas formas: distributiva e corretivamente. O direito, nesta acepção, se define por possuir um objeto, uma proporção e um método (o dialético) e pode ser caracterizado como a arte da partilha proporcional de bens exteriores entre pessoas. Eis, em linhas gerais, o conceito de direito de Aristóteles.

A partir disso, cabe analisar um exemplo de como a concepção de justiça acima exposta tem estreita ligação com a forma como o filósofo pensou temas essências de sua Filosofia, tal como a democracia, regime político que nos foi legado ${ }^{10} \mathrm{e}$ cujas lições encontram-se naquele que é um dos grandes clássicos da Antiguidade, a obra Politica.

\section{A DEMOCRACIA: O GOVERNO DOS POBRES E LIVRES}

Inicialmente, se deve notar que apesar do grande florescimento que este regime político encontra hoje, os gregos antigos ${ }^{11}$ não o viam com bons olhos, tendo legado à posteridade não um elogio, mas uma "crítica da democracia" (COSTA, 2010, p. 212).

Aristóteles, por exemplo, considerava a democracia como um regime desviado.

Na Política, Aristóteles reserva muitas páginas ao estudo da Democracia, especialmente nos Livros III a VI. No livro III, ele começa seu estudo indagando qual a natureza da democracia.

Desta forma, a primeira observação de Aristóteles é que não se deve definir um regime pelo critério numérico. Por exemplo, não seria correto dizer que a democracia é o governo dos muitos, assim como a oligarquia é o governo dos poucos, pois o número é apenas um "atributo acidental” já que:

[...] podemos conceber um caso em que, sendo a democracia o regime em que a multidão governa, a maioria é composta por indivíduos ricos que têm o poder supremo; similarmente, sendo a oligarquia o regime em que o poder pertence a um pequeno número, poder-se-ia conceber o caso em que as classes mais pobres, embora menores em número do que as classes mais ricas, fossem mais fortes do que estas e exercessem o poder supremo no regime. (Pol. 1279b20-25).

Ou seja, um regime no qual uma maioria de ricos governa não é por isso uma democracia e sim uma oligarquia. A melhor definição, segundo Aristóteles, é a que considera existir uma democracia quando o regime visa o interesse dos pobres e uma oligarquia quando o interesse perseguido for o dos ricos: "quando o poder se exerce em virtude da riqueza, quer sejam poucos ou muitos, trata-se de uma oligarquia; quando os pobres governam trata-se de uma democracia." (Pol. 1280a40).

Aristóteles esclarece ainda que a razão do critério numérico ser sempre invocado é que "os ricos são em

\footnotetext{
${ }^{10}$ Não sem considerar sobre esta afirmação a advertência de Pietro Costa, segundo o qual a democracia é um dos "grandes conceitos”. Ou seja, é semanticamente carregada, reinventando-se ao longo dos séculos nos mais diversos contextos culturais. Portanto, para se analisar o conceito grego de democracia, é preciso levar em conta que a História não se faz sem mediações e está longe de se constituir numa continuidade de sentido, sem interrupções ou retrocessos. (COSTA, 2010, p. 223).
} 
todo lado poucos e os pobres muitos" (Pol. 1279b35), de modo que se identifica os pobres à multidão e os ricos ao menor número.

Em segundo lugar, quando se procura entender de que natureza é um regime, deve-se perguntar em nome de que uns e outros reclamam o poder.

Assim, na oligarquia os ricos reclamam o poder em nome da riqueza, já que ela é de poucos. Já os pobres o fazem em nome da liberdade uma vez que a "liberdade é de todos ${ }^{12}$." (Pol. 1280a5).

Ocorre que Aristóteles considera ambos os regimes desviados, precisamente porque a democracia visa o interesse dos pobres e a oligarquia o interesse dos ricos.

Para ele um regime correto é aquele que visa o "interesse da comunidade", e não apenas de uma fração ou parte dela, ainda que o interesse atendido seja o da maioria: "Quando o único, ou os poucos, ou os muitos, governam em vista do interesse comum, esses regimes serão necessariamente retos. Os regimes em que se governa em vista do único, dos poucos, ou dos muitos são transviados." (Pol. 1279a25-30)

Com base neste critério, Aristóteles apresenta como regimes retos, o regime constitucional (politéia), a aristocracia e a realeza. E como regimes desviados a democracia, a oligarquia e a tirania ${ }^{13}$.

Cada um destes regimes elege o seu próprio critério de distribuição da justiça. Na oligarquia, como já dito, o critério é a riqueza, na democracia é a liberdade, e na Aristocracia, a virtude (ou mérito).

A democracia é um regime desviado porque se caracteriza por negligenciar os ricos, expropriando-os despoticamente de sua riqueza ${ }^{14}$, da mesma maneira que a oligarquia é desviada por negligenciar os pobres (Pol. 1310a5). Porém, isto não significa dizer que não haja justiça na democracia, já que a democracia realiza uma espécie de justiça, a justiça democrática.

Contudo, para Aristóteles só são corretos aqueles regimes que realizam a justiça sem reservas, quer dizer para todos, e a democracia realiza uma justiça que é, na melhor das hipóteses, uma justiça parcial.Veremos a seguir o que isto significa.

\footnotetext{
${ }^{11}$ Referindo-se a Platão e Aristóteles (ainda que manifestem essa avaliação de ponto de vistas diferentes).

${ }^{12}$ Esse é o argumento dos democratas, não o de Aristóteles, pois como se verá o filósofo entende que a liberdade é atributo do cidadão ou dos senhores naturais, não se incluindo os escravos, as mulheres e os estrangeiros. Porém, os democratas encontraram na liberdade um critério de distribuição da justiça que eles possuem em igualdade com todos os demais, inclusive com os ricos.

${ }^{13}$ As três últimas são deteriorações das três primeiras, sendo que Aristóteles considera a democracia como o melhor dos regimes desviados. Com efeito, ele afirma: "De fato, pode muito bem suceder que a oligarquia e a democracia sejam perfeitamente admissiveis, ainda que estejam longe da melhor ordem." (Pol. 1309b30).

${ }^{14}$ É a imagem da multidão que se impõe aos ricos, sobretudo através da figura dos demagogos: "As democracias alteram-se com muita facilidade em virtude da intervenção facciosa dos demagogos: estes denunciam ardilosamente os ricos proprietários que, assim, são levados a aliar-se (o medo recíproco chega a unir os piores inimigos); ou então incitam publicamente o ânimo dos populares contra as classes abastadas." (Pol. 1304b20-25). E mais adiante acrescenta: "os demagogos, para favorecer a classe popular, tratam injustamente os notáveis, quer repartindo as riquezas deles, quer reduzindo os seus rendimentos com maiores impostos; noutros casos lançam calúnias contra os notáveis no intuito de lhes confiscar os bens." (Pol. 1305a5)
} 


\section{A JUSTIÇA RELATIVA DAS DEMOCRACIAS}

\section{O critério da Igualdade}

O filósofo grego, ao tratar da igualdade democrática, principia esclarecendo a maneira pela qual os partidários da democracia compreendem a justiça: como igualdade numérica, sem considerar o mérito dos cidadãos.

O "elemento supremo" do regime democrático, escreve Aristóteles, é a massa de cidadãos. Ou seja, uma vez que o critério de justiça adotado é o numérico, prevalece consequentemente o entendimento de que a maioria é suprema: o ato de decidir segundo uma maioria é a finalidade da democracia: "Na verdade há quem diga que cada cidadão deve possuir o mesmo que os restantes; o que acontece por via disso nas democracias é que os pobres são mais poderosos que os ricos, pois são em maior número, e o que prevalece é a opinião da maioria." (Pol. 1317b5)

A respeito desta forma de invocar a igualdade, a crítica de Aristóteles observa que:

[...] há quem considere que a justiça consiste na igualdade. Assim é, com efeito, mas não para todos e apenas para os que são iguais. Outros consideram que é justa a desigualdade; e na verdade assim é, mas unicamente para aqueles que são desiguais e não para todos. Ambos os argüentes ignoram os destinatários dos princípios de justiça e cometem erros de juízo" (Pol. 1280a10-15)

Alicerçar o princípio democrático na igualdade significa desviar o objetivo da Política que não é transformar os homens em absolutamente iguais, mas ao contrário, tirar proveito de suas diversas aptidóes naturais ou conquistadas por mérito.

Ademais, se é verdade que há igualdade (do ponto de vista de que a todos se atribui a liberdade) isto não significa que de outros pontos de vista todos os homens sejam iguais. Atribuir os mesmos direitos políticos a todos importa em negar que alguns são superiores em virtude ${ }^{15}$ e por isso merecem um tratamento diferente:

\footnotetext{
${ }^{15}$ Isso ocorre porque para Aristóteles o melhor critério para escolher um governante deve ser aquele que leva em conta a virtude ou a excelência. Isto é, deve governar aquele que tem mais capacidade para tanto e por isso desempenha melhor a função de governante: "Um cidadão é, em geral, o que alternadamente governa e é governado [...]. No regime melhor, é cidadão aquele que é capaz e que escolhe deliberadamente governar e ser governado, visando uma vida virtuosa”. (Pol. 1284a40). Assim sendo, se o cidadão é aquele que é capaz de governar porque antes aprendeu a obedecer, estas capacidades não são dadas pelo nascimento, embora seja verdade que "os que descendem dos melhores serão melhores já que o bom nascimento é uma virtude da estirpe" (Pol. 1283a35). Porém, para governar se exige mais, requer-se a principal virtude do cidadão e do governante: a prudência ou a capacidade de previsão. Pode-se ver a posição de Aristóteles sobre este assunto em pelo menos duas passagens da Política. A primeira em 1281a40: "É preciso concluir que a comunidade política existe graças às boas ações, e não a simples vida em comum. Aos que contribuem mais para este tipo de comunidade, cabe-lhes uma parte maior na cidade do que aqueles que são iguais ou mesmo superiores em nascimento e em liberdade, embora inferiores em virtude cívica [excelência política]; e cabe-lhes mais do que aqueles que os superam em riqueza mas não em virtude." E a segunda em 1282b: "é possível argumentar que as magistraturas deveriam ser distribuídas desigualmente com base numa superioridade qualquer, qualquer que fosse o bem, desde que os cidadãos nada difiram em outros aspectos, mas pelo contrário sejam completamente semelhantes. Com efeito, indivíduos diferentes têm direitos e méritos diferentes. Se este argumento for verdadeiro, a cor a estatura ou outra característica de excelência, conferem aos que a possuem uma certa pretensão a maiores direitos políticos? O erro salta a vista e evidente nas outras artes e ciências; entre
} 
Na perspectiva da vida boa, seria justo atender sobretudo à educação e à virtude, como já referimos. Não devem ter igualdade em tudo aqueles que são iguais apenas num aspecto, e não devem ter desigualdade em tudo os que são desiguais também só num aspecto. Os regimes que se fundam nestas pretensões (nascimento [livre] e riqueza) são transviados. Notamos antes que estas pretensões são justas num certo sentido, mas não em absoluto. (Pol. 1283a25-30)

Além disso, recoloca-se a questão da espoliação da minoria de ricos que teria de ser desapropriada de sua riqueza se o critério da igualdade fosse mantido à risca.

Por estas razões, Aristóteles afirma que adotar como critério de distribuição da justiça a igualdade plena das democracias, é uma pretensão justa “num certo sentido". Isto é, para alcançar a igualdade de todos os bens é preciso eliminar as diferenças, o que significa atender a apenas uma parte (a que deseja ser igual). Ora, atender apenas uma parte (ainda que ela seja a maior) significa para o filósofo realizar uma justiça também apenas parcial.

\section{O critério da liberdade}

Infelizmente, não há maior êxito em se estabelecer como critério das democracias, a liberdade.

De fato, se o critério eleito é a liberdade assegura-se a autonomia individual. Isto é, que cada qual não será dominado, porém se esquece que ser comandado também é vantajoso. A neutralidade democrática ("todos são iguais, todos são livres") deixa de lado a preocupação com a justiça que é alcançada não por um comportamento de abstenção, mas por um comportamento positivo, de interferência por meio da educação dos cidadãos e do hábito para a virtude ${ }^{16}$.

Para Aristóteles, os democratas possuem uma concepção equivocada da liberdade ${ }^{17}$, entendendo-a como "tolerar modo de vida que cada um quiser" (Pol. 1319b25). Assim ele apresenta o argumento democrata:

Outro sinal distintivo da liberdade é o fato de cada um viver como quiser. Nesse sentido, há quem diga que a ação da liberdade resulta dessa vontade, pois de fato é próprio do escravo não viver de acordo com a sua vontade. Esta é, portanto, a segunda regra determinante da democracia, e dela decorre a vontade de não se ser, na melhor das hipóteses governado por ninguém, ou então, se tal não for possível, ser governado por alternância. Este sinal distintivo contribui para a liberdade tomada em acepção igualitária. (Pol. 1317b10-15).

Aristóteles não nega que há uma certa concepção de justiça em vigor na democracia, porém esta acepção

\footnotetext{
tocadores de flauta igualmente hábeis na sua arte, não seriam, de preferência, os bem nascidos a ser dotados de flautas pois não é o mais bem nascido o que toca melhor; a quem desempenhar melhor o seu trabalho, deve ser dado o melhor instrumento. Se ainda não ficou claro o que referimos, mais evidente ficará se insistirmos neste ponto. Se um tocador de flauta se destaca na sua arte mas é inferior em bom nascimento e beleza; e mesmo que tais qualidades superem a arte da flauta numa proporção superior à que o melhor tocador de flauta supera os seus companheiros de arte; não obstante, é a ele que deveremos das as melhores flautas. Mas se fosse como acabamos de dizer, a superioridade de riqueza e o bom nascimento deveriam contribuir para o desempenho dessa função mas o fato é que não contribuem."

16 "De todos os meios aqui referidos para assegurar a conservação dos regimes políticos, o que se afigura mais importante é o que se encontra hoje menosprezado: a educação cívica.” (Pol. 1310a10).

17 "Mesmo nessas democracias que se presumem as mais representativas das massas populares, acaba por acontecer o contrário do que é mais adequado ao interesse comum. A razão é a má compreensão da liberdade. Com efeito, a democracia parece alicerçar-se em duas bases: o poder supremo da maioria e a liberdade." (Pol. 1310a25)
} 
"igualitária”, como ele a chama, está longe de se constituir no melhor sentido de justiça:

No regime democrático, a justiça parece consistir na igualdade : uma igualdade fundada na opinião da maioria - pois a opinião é considerada suprema - e a liberdade e igualdade de cada um fazer aquilo que muito bem lhe apraz. Nas democracias, por conseguinte, cada um procede de acordo com aquilo que pretende, e para onde o impulso lhe conduz', segundo as palavras de Eurípedes. Ora uma tal situação é iníqua: o viver de acordo com o estabelecido pelo regime não deve ser considerado como servidão; pelo contrário, deve ser a salvaguarda do regime. (Pol. 1310a30-35).

Isto é, para Aristóteles, esse modo de conceber a liberdade é sintoma de um "viver desordenado" (Pol. 1319b25) que é próprio dos escravos e não dos homens livres e virtuosos cujo viver é sensato ${ }^{18}$.

Além disso, ele refere nessa passagem aquilo que Pietro Costa também notou ${ }^{19}$. Segundo o professor italiano a "liberdade antiga" apresenta uma "estreita conexão entre o indivíduo e a comunidade política". Como se lê na passagem acima citada trata-se de "viver de acordo com o estabelecido pelo regime". Vale dizer:

Não falta a consciência de uma dimensão 'individual' da liberdade; a liberdade, porém, não é o único atributo do indivíduo como tal, nem é referível a todo indivíduo: deve ser colocada em relação de oposição com a escravidão, deve fazer frente a uma estrutura hierarquicamente ordenada em torno da figura dominante do pater, deve, enfim, estar ligada à relação de pertencimento à comunidade política. (COSTA, 2010, p.224)

Esta concepção antiga da liberdade fica mais clara quando se verifica que para o filósofo é totalmente estranha a ideia moderna de que os homens são todos "a prior" igualmente livres.

Na Política, Aristóteles expõe a noção de que existem escravos naturais. Estes são aqueles que sendo inteiramente homens recusam o exercício do Direito em virtude de uma inclinação pessoal para a servilidade, no sentido de que não compartilham as aspirações do homem enquanto cidadão. Eles nem mesmo partilham do objetivo comum, fim da cidade, o bem viver, entendido como perfeita autossuficiência: saber reconhecer e tomar para si o melhor fim ${ }^{20}$ o que constitui a liberdade.

Com esta concepção Aristóteles "evita [...] promover a princípio absoluto do direito uma aspiração desigualmente compartilhada entre os homens, a saber, a liberdade." (Bodeüs, 2010, p. 376). Deste modo, a

\footnotetext{
${ }^{18}$ Ou prudente, porque fruto da deliberação "a tarefa própria da inteligência política." (Pol. 1290a 25). Não é a toa que Aristóteles caracteriza o escravo como aquele que "não tem faculdade deliberativa". (Pol. 1260a10).

${ }^{19} \mathrm{Na}$ interpretação de Pietro Costa sobre a liberdade antiga: "a liberdade não é uma característica imediata da figura do cidadão. Livre é em primeiro lugar a cidade, enquanto o cidadão é livre enquanto membro de uma cidade livre" (COSTA, 2010, p. 225).

${ }^{20} \mathrm{O}$ melhor fim que a função do homem pode alcançar consiste no "exerćício e uso perfeito da virtude" (Pol.1332a5-10), precisamente a eudaimonia (felicidade). Na Ética a Nicômaco lê-se o seguinte: "A vida parece ser comum até às próprias plantas, mas agora estamos procurando o que é peculiar ao homem. Excluamos, portanto, a vida de nutrição e crescimento. A seguir há uma vida de percepção, mas essa também parece ser comum ao cavalo, ao boi e a todos os animais. Resta, pois a vida ativa do elemento que tem um princípio racional; desta uma parte tem tal princípio no sentido de ser-lhe obediente, e a outra no sentido de possuí-lo e de exercer o pensamento. E como a vida do elemento racional também tem dois significados, devemos esclarecer aqui que nos referimos à vida no sentido de atividade; [...] a função do homem é uma atividade da alma que segue ou que implica um princípio racional." (EN 1097b30 a 1098a 10). E mais adianta acresce: "uma certa espécie de vida, e esta vida uma atividade ou ações da alma que implicam um princípio racional; e acrescentamos que a função de um bom homem é uma boa e nobre realização das mesmas.[...] o bem do homem nos aparece como uma atividade da alma segundo a virtude, e se há mais de uma virtude, com a melhor e mais completa. Mas é preciso ajuntar numa vida 'completa'. Porquanto uma andorinha não faz verão, nem um dia tampouco; e da mesma forma um dia, ou um breve espaço de tempo, não faz um homem feliz e venturoso." (EN 1098a5-15)
} 
liberdade e a igualdade não são os fundamentos do Direito em Aristóteles (a sua natureza ${ }^{21}$ ), ou seja, condições sem as quais o Direito não seria justo. Elas são, na verdade, as condições necessárias do Direito, sem as quais ele simplesmente não se aplica ${ }^{22}$ : a lei só se aplica entre livres e iguais, porém nem todos são iguais e livres. Os escravos estão fora do âmbito de aplicação do Direito, motivo pelo qual Aristóteles afirma que entre senhor e escravo existe apenas uma justiça por semelhança ${ }^{23}$.

Além disso, a atribuição de igual liberdade a todos, não negligencia apenas os escravos naturais, que mereceriam um tratamento diferenciado ${ }^{24}$, mas também aqueles indivíduos que são muito superiores: " $O$ ostracismo, a seu modo, também tem o efeito de eliminar ou exilar os cidadãos que se destacam." (Pol. 1284a35).

Aqueles que são muito superiores ameaçam o regime democrático que visa à igualação de todos os bens $^{25}$. Desta forma, surge nas democracias a lei do ostracismo, medida legal de segurança que tem como objetivo resguardar os regimes democráticos da dissolução.

De acordo com Aristóteles, esta lei é justa se considerada do ponto de vista do princípio de justiça das democracias, que persegue a absoluta igualdade dos cidadãos, mas não é justa sem reservas, isto é, absolutamente justa $^{26}$. Ele diz:

\footnotetext{
${ }^{21}$ O princípio formal do direito, já referido, é atender ao interesse comum sem privilegiar uma fração em detrimento da outra.

${ }^{22}$ Cf. Bodeüs, Richard. Os fundamentos naturais do direito e a filosofia aristotélica (In: ZINGANO, 2010).

${ }^{23}$ Ou por analogia, que de resto não é verdadeira justiça. Aristóteles escreve a respeito na Ética a Nicômaco: "Metaforicamente e em virtude de uma certa analogia, há uma justiça não entre um homem e ele mesmo, mas entre certas partes suas. Não se trata, no entanto, de uma justiça de qualquer espécie, mas daquela que prevalece entre amo e escravo ou entre marido e mulher. Pois tais são as relaçōes que a parte irracional da alma guarda para com a parte racional; e é levando em conta essas partes que muitos pensam que um homem pode ser injusto para consigo mesmo, a saber, porque as partes em apreço podem sofrer alguma coisa contrária aos seus desejos. Pensa-se, por isso, que existe uma justiça mútua entre elas, como entre governante e governado." (EN 1138b5-10) Note-se que Aristóteles usa o mesmo termo para caracterizar os indivíduos muito superiores em virtude "os que se assemelham" a Zeus, para quais o direito também não se aplica porque eles próprios são a lei: "Se existir um indivíduo ou vários (mas insuficientes para formar a população da cidade) tão preeminentes em virtude que nem a virtude nem a capacidade política dos outros se possam comparar à deles (se forem vários) ou às suas, (se for um só), um tal indivíduo, ou indivíduos, não devem ser tratados como simples partes da cidade. Tratá-los-emos injustamente se apenas os acharmos dignos de direitos iguais, sendo eles tão desiguais em virtude e em capacidade política. Um indivíduo assim tornar-se como um Deus entre os homens. Por aqui se vê que a legislação se refere necessariamente àqueles que são iguais em nascimento e capacidade, enquanto para os seres superiores não existe lei; eles mesmo são a lei. Seria estultícia tentar legislar para eles: retaliariam com palavras usadas pelos leões da fábula de Antístenes, quando as lebres reivindicaram, em assembléia, a igualdade para todos." (Pol. 1284a5-15)

${ }^{24}$ Trata-se da aplicação de um princípio de justiça distributiva. Por justiça distributiva se pode entender a atribuição a pessoas de divisões de bens. Essa distribuição será considerada justa apenas se pessoas iguais receberem parcelas iguais. Aristóteles nota que é mais fácil estabelecer a divisão igualitária das coisas do que a igualdade das pessoas: "pois todos admitem que a distribuição justa deve concordar com o mérito num sentido qualquer, se bem que nem todos especifiquem a mesma espécie de mérito..." (EN 1131a25).

${ }^{25}$ Disso decorrertambém que nesse regime vigore a suspeição com relação a todo tipo de superioridade, vista como antidemocrática. Ora, esse tipo de justiça revela os limites da democracia, uma justiça parcial que não abarca verdadeiramente a todos.

${ }^{26}$ Conforme já explicou antes, o critério utilizado por Aristóteles para definir os regimes corretos não é o do número de pessoas no poder (o governo da maioria ou da minoria, pol. 1279b30-35), mas o que distingue o bom do mau governo é se a autoridade é exercida no interesse de todos ou se é exercida apenas em benefício dos governantes. Em outros termos, se o governo atende ao interesse comum e não apenas ao de uma fração, ainda que seja a da maioria: "A conclusão que se segue é clara: os regimes que se propõe atingir o interesse comum são retos, na perspectiva da justiça absoluta; os que apenas atendem aos interesses do
} 
O argumento em prol do ostracismo possui alguma justificação quando se funda numa reconhecida superioridade. Seria preferível que o legislador, desde o início, concebesse um regime que não carecesse de tal remédio; só em segundo lugar, em caso de necessidade, tentaria remediar a situação com o referido corretivo. Mas na realidade não é isto que tem sido aplicado nas cidades; em vez de considerar o interesse do próprio regime, recorre-se ao ostracismo com intuito faccioso.

Nos regimes transviados é manifesto que esta prática é vantajosa e justa em relação aos regimes particulares, mas é evidente que não é justa falando absolutamente. Contudo, no regime melhor, o recurso ao ostracismo suscita uma grave dificuldade. A dificuldade não resulta de uma preeminência fundada em qualidades tais como o poderio, a riqueza ou a popularidade, mas no fato de alguém se destacar em virtude. Como proceder neste caso? Ninguém diria, decerto, que se deveria banir ou mandar para o exílio tal individuo. Nem se diria, tão pouco, que deveria estar submetido ao poder dos demais. Isso seria como pretender governar Zeus, partilhando o governo com ele. A alternativa que resta - e que parece fundada na natureza - é que todos obedeçam voluntariamente a um tal homem; desse modo, os que se the assemelham seriam para sempre reis na sua cidade. (Pol. 1284b1534)

Assim, parece a Aristóteles uma violência banir os indivíduos mais virtuosos.

Enfim, por todos esses fatores, a democracia alcança no máximo um certo sentido de justiça. Ou seja, uma justiça relativa, como escreve Pietro Costa: "[...] a democracia evoca a ideia de um regime ligado aos interesses de uma parcela social específica e incapaz de refletir os interesses da totalidade" (COSTA, 2010, p. 213).

Por conseguinte, a reflexão que faz Aristóteles sobre o regime político da democracia demonstra como é complexa sua teoria da justiça anteriormente exposta, complexidade esta que traz consigo riqueza de compreensão e profundo entendimento na apreciação desses vários aspectos, pois como ele diz, a justiça não é um conceito unívoco, dizendo-se de muitos $\operatorname{modos}^{27}$. Os regimes considerados desviados, ao elegerem seu critério de distribuição de justiça, o fazem privilegiando um ou outro aspecto, aquele que serve à "parte” (ou grupo) que está no poder (justiça relativa), alijando os que não se encaixam no critério escolhido e assim olvidando que a justiça sem reservas só pode ser alcançada no todo da comunidade política.

\section{CONSIDERAÇÕES FINAIS: A ATUALIDADE DA CONCEPÇÃO DE JUSTIÇA DE ARISTÓTELES}

Deste modo, procurou-se apresentar uma leitura possível da concepção de justiça de Aristóteles dentro da História da Filosofia, a partir de questões importantes para a filosofia do direito moderna e contemporânea que

\footnotetext{
governantes são defeituosos e todos eles desviados dos regimes retos." (Pol. 1279a20).

${ }^{27}$ Aristóteles possuía grande perspicácia para enxergar os princípios mais fundamentais do real, como por exemplo, as distinções que cunhou entre ato e potência, substância e acidente, a tríade princípio de não-contradição/princípio de identidade/princípio do terceiro excluído, práxis e poiésis, ação e produção, matéria e forma etc., as quais explicam de modo simples as coisas, e, no entanto, são de difícil apreensão. Essa dificuldade resulta da tentativa de explicar o real partindo daquilo que comumente se entende entre os homens. Isto é, das opiniões comuns ou daquilo que está ao alcance de todos, complexidade esta que trará muitas vezes contradição, mas ao mesmo tempo riqueza de compreensão, o que ajuda a compreender a frase corrente de Aristóteles em todos os seus escritos segundo a qual o "ser de diz de muitos modos", "a justiça se diz em muitos sentidos", etc.
} 
são dirigidas à obra do filósofo, cuja matriz se pode remontar à leitura latina de seu pensamento de raízes romanas e medievais.

Nesse sentido, uma boa forma de conferir a influência que o pensamento do filósofo grego exerce até os dias de hoje $\mathrm{e}^{28}$ é atentar para o debate ${ }^{29}$ contemporâneo entre os liberais kantianos ${ }^{30}$ de um lado e os comunitaristas de outro, sobre a questão de como pensar a cidadania com vistas a um regime democrático e plural.

De forma bastante resumida e simplificada, os liberais kantianos defendem que é possível uma ideia universal de bem comum, portanto de liberdade e igualdade, em suma um direito universal porque baseado em princípios de justiça comuns a toda pessoa humana.

Já os comunitaristas contra-argumentam que tal bem universal não existe porque pessoas pertencem a comunidades específicas, e, logo, a culturas diferentes que são irredutíveis umas as outras.

Deste modo, da compreensão dos liberais kantianos resulta uma concepção meramente formal de bem comum, a qual por ser aplicável a todos, em verdade, não é aplicável a ninguém. Isso acontece porque uma única concepção de bem comum ignora a especificidade de cada povo, de cada cultura ${ }^{31}$.

Do lado dos comunitaristas, há um bem comum substantivo, pois relativo sempre aos direitos, usos e costumes de uma comunidade em especial. Porém, este bem (ou comunidade) resta totalmente isolado, dada a impossibilidade de comunicação entre culturas "diferentes" ou particulares, para as quais caberia apenas respeitar as diferenças sem qualquer possibilidade de intervenção.

Este debate lembra aquele muito mais antigo que se discutiu nos tópicos precedentes deste artigo, entre Aristóteles, Platão e os sofistas. E então se chamava a atenção precisamente para a originalidade da resposta de Aristóteles na tentativa de superar a dicotomia fundamental entre os diversos direitos positivos de um lado (a convenção específica de cada comunidade política) e um substrato comum a elas que não fosse meramente uma

\footnotetext{
${ }^{28}$ Aliás, no campo da filosofia do direito é enorme a influência de Aristóteles. Apenas para citar alguns exemplos: 1. a nova retórica de Chaim Perelman, dos anos 50 do século XX, levou em consideração as técnicas de argumentação e persuasão presentes na Retórica e nos Tópicos de Aristóteles: "Nova retórica' é o nome que o próprio Perelman deu à teoria da argumentação por ele proposta no Traité e que se inspira diretamente e explicitamente em Aristóteles." (Berti, 1997, p. 287); 2) na Alemanha, o filósofo do direito Theodore Vieweg, na obra Topik und Jurisprudenz (1953) demonstra como o método aristotélico tópico-dialético ainda é muito usado pela Jurisprudência; 3) Por sua vez, o francês Michell Villey, já mencionado, referindo-se à importância de Aristóteles afirma que "ele foi a nossos olhos o primeiro filósofo do direito no sentido estrito. [...] Devemos-lhe ter descoberto o conceito do direito." (2007, p. 34-35). Deste modo, retoma muito temas do filósofo grego, como por exemplo, a obra Nova retórica e direito natural na mesma linha de Perelman; 4) Alain Renaut e Lukas Sosoe apontam ainda em Jonh Rawls a presença de Aristóteles. Rawls, na terceira parte de sua Teoria da Justiça, desenvolve o que nomeia como o "princípio aristotélico". De acordo os autores acima citados, "não são poucos os comentadores que sublinham na Teoria da Justiça um « tratamento quase aristotélico da doutrina (moderna) do contrato social»" (RENAUT; SOSOE., 1991, p.233)

${ }^{29} \mathrm{O}$ debate está bem caracterizado no texto de Chantal Mouffe, A cidadania democrática e a comunidade política. Disponível em: http://WWW.fclar. unesp.br/publi/publicações/art5.htm.

${ }^{30}$ Por exemplo, John Rawls.
} 
universalidade separada, uma abstração (o direito natural tal como em Platão). Aristóteles afirmou, contra os sofistas, que essa polaridade não existia, até porque as coisas humanas não se dão desta maneira na realidade, e o que se constata é que as comunidades políticas não são ilhas isoladas, por mais distintas que possam ser "pois há na natureza um princípio comum do que éjusto e injusto, que todos de algum modo adivinham mesmo que não haja entre si comunicação ou acordo." ( Ret.1373b)

Apenas do breve estudo que se empreendeu até aqui, é possível perceber que a solução do dilema não é simples, mas as páginas de Aristóteles, mesmo depois de séculos, podem ajudar aquele que se debruça sobre elas a pensar esse bem comum, por exemplo, como ele pensou o seu direito natural, enquanto possibilidade de tradução, como o lugar de conversão dos vários direitos diversos. Isto é, enquanto o horizonte sobre o qual os direitos positivos devem ser considerados, como aquilo que "é ao mesmo tempo o que torna possível e o que visa ao direito positivo ${ }^{32}$.

A filosofia do direito de Aristóteles, a forma complexa como ele apresenta a sua concepção de justiça (que se diz de muitos modos), a originalidade com que ele articula esses sentidos, serviram como fundamento para a análise crítica que ele empreendeu acerca dos regimes políticos de seu tempo, e nos foram legadas como importantes ferramentas, para tomá-lo na acepção referida na epígrafe que dá abertura a este trabalho: como inspiração para o próprio refletir, para o próprio filosofar sobre os dilemas atuais, para enfrentar os dilemas de nosso tempo.

\section{ARISTOTLE: JUSTICE IS TOLD IN MANY WAYS}

\section{Abstract}

The present article analyzes the conception of justice in Aristotle and the place that law occupies in it. The justice, for the Greek philosopher, it is not a univocal term, but is presented in different ways. Initially, we try to clarify these ways with the support on contemporary literature and departing from questions raised by the philosophy of law. Next, using the hermeneutic method to analyze and comment passages from the text of the Book Politics, we examine a practical example of Aristotle's application of that concept, through the critic study he makes of the political regime of democracy. Finally, after presenting a possible reading of that conception of justice, which

\footnotetext{
${ }^{31}$ Para Aristóteles a forma só se realiza em uma matéria (um conteúdo), só existe na "forma" de uma coisa específica, de um indivíduo determinado. A forma sem a matéria se esvai.

${ }^{32}$ A citação completa é ainda mais esclarecedora "A primeira maneira de interpretar essa 'imanência” do direito natural aristotélico é a mais simples, mas também a mais fraca, para não dizer a mais falsa. Ela consistiria em dar à imanência o sentido de um relativismo fundamental: se existe um justo natural, seria estritamente imanente às comunidade históricas. A segunda maneira consiste em realçar que essa imanência é pensada por Aristóteles no quadro da pesquisa de um optimum político, quer dizer, de uma forma de universalidade natural. Nesse sentido, a imanência do justo natural não é pensável senão quando se recorda que o eidos platônico é conservado por Aristóteles: não é somente a 'forma' de uma comunidade histórica particular de direito positivo, mas a forma do próprio direito. É por essa razão que a sugestão de uma analogia com a idéia reguladora kantiana pode ser aceitável: o direito natural aristotélico é ao mesmo tempo o que torna possível e o que visa ao direito positivo." (Billier, 2005, p. 85).
} 
reveals the originality of Aristotle in the way he articulates all those senses of justice, and already by way of conclusion, we illustrate the actuality of the aristotelian philosophy of law by pointing its presence on the debate between communitarianists and liberals concerning the best way of thinking citizenship and democracy.

Keywords: Aristotle; philosophy of law; justice; natural law; democracy.

\section{REFERÊNCIAS BIBLIOGRÁFICAS}

ARISTÓTELES. Ética a Nicômaco. Trad. Leonel Vallandro e Gerd Bornheim. In: Coleção Os Pensadores. São Paulo (SP): 1987.

Política. Trad. E notas António Campelo Amaral e Carlos de Carvalho Gomes. Portugal: Vega Universidade

Retórica. 2ed. rev. Obras completas de Aristóteles. vol VIII, tomo I. Lisboa (Portugal): Imprensa Nacional - Casa da Moeda, 2005.

BERTI, Enrico. Aristóteles no século XX Trad. Dion D. Macedo. São Paulo (SP): Loyola, 1997.

BILLIER, Jean-Cassien; MARYIOLI, Agla. História da filosofia do direito. Trad. Maurício de Andrade. Barueri (SP): Manole, 2005.

BODEÜS, Richard. Aristóteles: a Justiça e a Cidade. São Paulo (SP): Loyola, 2007.

Os fundamentos naturais do direito e a filosofia aristotélica. In: ZINGANO, Marco (Org). Sobre a ética nicomaquéia de Aristóteles: textos selecionados. São Paulo (SP): Odysseus, 2010.

BRUGNERA, Nedilson Lauro. A escravidão em Aristóteles. Porto Alegre: EDIPUCRS, Editora Grifos, 1998. (Coleção Filosofia; n. 79).

COSTA, Pietro. Soberania, representação, democracia: ensaios de História do Pensamento jurídico. Coord. Ricardo Marcelo Fonseca. Curitiba (Pr): Juruá, 2010, p. 213.

MARINHO, Inezil Penna. O direito natural na Grécia antiga. Brasília (DF): Instituto de direito natural, 1978.

MATA, José Veríssimo Teixeira da. Aristóteles. In: MARÇAL, Jairo (Org.). Antologia de textos filosóficos. Curitiba: SEED - Pr., 2009.

MOUFFE, Chantal. A cidadania democrática e a comunidade política. Disponível em: http://WWW.fclar. unesp.br/publi/publicações/art5.htm.

RENAUT, Alain; SOSOE, Lukas. Philosophie du droit. Paris (França): Presses Universitaires de France, 1991.

VILLEY, Michel. O direito e os direitos humanos. Trad. Maria E. de A. P. Galvão. Coleção Justiça e Direito. São Paulo (SP): WMF Martins Fontes, 2007.

YOUNG, Charles M. A justiça em Aristóteles. In: KRAUT, Richard. (Org.). Aristóteles: a ética a Nicômaco. Trad. Alfredo Storck. Porto Alegre (RS): Artmed, 2009. 
Quaestio Iuris

Trabalho enviado em 25 de setembro de 2016. Aceito em 16 de abril de 2017. vol. 11, no. 01, Rio de Janeiro, 2018. pp. 154172 DOI: $10.12957 /$ rqi.2018.25763 